\title{
Lysine Requirement of the Adult Rooster
}

\author{
Teru Ishibashi and Masao Kametaka \\ Department of Agricultural Chemistry, Faculty of Agriculture, \\ The University of Tokyo, Tokyo 113 \\ (Received January 28, 1977)
}

The amino acid requirements of adult roosters determined by a nitrogen balance method have been reported by Ishibash ${ }^{17}$ and Leveille et al. ${ }^{2-5)}$ The comparison of the former with the latter indicates three qualitative differences besides small quantitative differences in amino acid requirements. In contrast to the results by Leveille et al. the data by Ishibashi indicated that 1) phenylalanine was replaceable with tyrosine for maintenance of nitrogen equilibrium for a long period ${ }^{6)}$ and both 2) histidine and 3) lysine were essential for maintenance of nitrogen equilibrium. The reexamination for the first and the second indications were conducted and the results confirmed were reported previously ${ }^{6-8}$.

Lysine is essential for growth and laying9). The lysine requirement was estimated to be 40 $\mathrm{mg} / \mathrm{kg}$ body weight/day (equivalent to $0.13 \%$ of the diet) for maintenance of the same level of $\mathrm{ni}$ trogen balance as observed on the whole egg protein diet and $16 \mathrm{mg} / \mathrm{kg}$ body weight/day (equiv. alent to $0.05 \%$ of the diet) for maintenance of nitrogen equilibrium ${ }^{11}$. On the other hand, LeverLLE et al. reported that the lysine requirement was no greater than $29 \mathrm{mg} / \mathrm{kg}$ body weight/day and the animais were not in negative nitrogen balance even in the complete absence of lysine from the diet.

Studies reported herein were designed to reinvestigate the lysine requirement of adult roosters by the nitrogen balance method and oxidation technique of lysine ${ }^{-14} \mathrm{C}$ to carbon dioxide in vivo and in vitro.

Eleven-month-old White Leghorn roosters weighing 1.90 to $2.20 \mathrm{~kg}$ were used in these experiments. This strain had been improved for earlier maturity and smaller size than usual in the National Institute of Animal Industry in Japan. The diets used contained $70.8 \%$ of corn starch, $5.0 \%$ of mineral mixture ${ }^{1}, 5.0 \%$ of cellulose powder, $5.0 \%$ of soybean oil, $1.8 \%$ of vitamin mix. ture $^{1)}, 10.0 \%$ of amino acid mixture (-lysine) $)^{1)}$ and $1.5 \%$ of lysine or glutamic acid. Four roosters were assigned to each treatment. Food and water were offered ad libitum for 10 days and excreta were collected during the last 4 days for nitrogen analysis.

At 10:00 A.M, on the 10 th day, $2.21 \mu \mathrm{Ci} \mathrm{L}-\mathrm{lysine}-\mathrm{U}-{ }^{14} \mathrm{C}$ per rooster was injected intraperitoneally. Expired carbon dioxide and excreta were collected for 8 hours ${ }^{8}$. At 8 hours after injection, all roosters were sacrificed by cutting subclavian artery. Then in vitro oxidation of lysine by the liver, kidney and small intestine homogenates was determined in the same way described by WANG and NeSHEIM ${ }^{10)}$. The radioactivity was determined in a liquid scintillation spectrometer ${ }^{8)}$.

成鵎のリジン要求量：石橋 晃・重高正夫 (東京大学農学部)

Jap. J. Zootech. Sci., 48, (6): 336-338, 


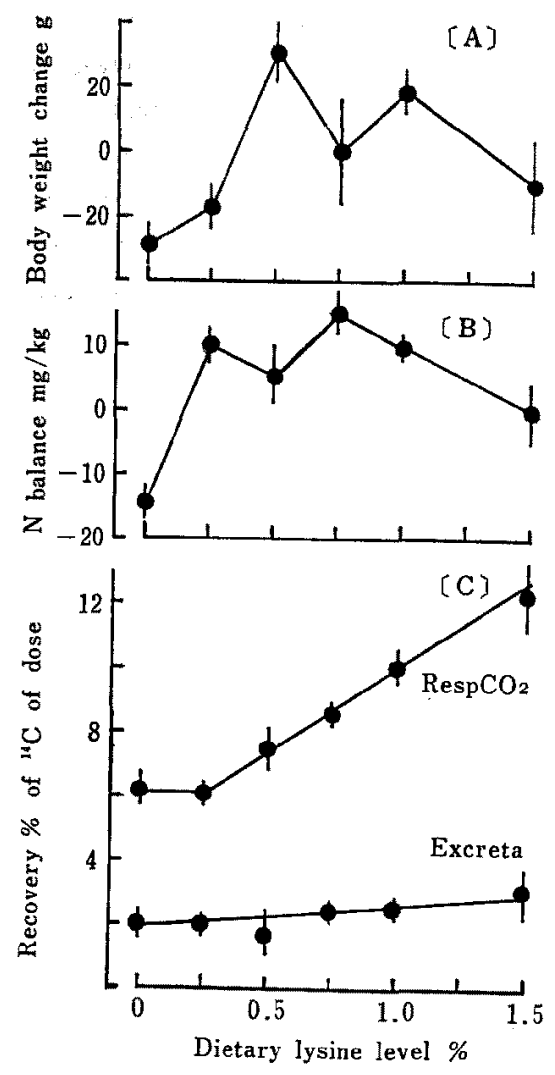

Fig. 1. Effects of dietary lysine levels on body weight changes (A), nitrogen balance (B) and recovery percentage of ${ }^{14} \mathrm{C}$ of dose in respiratory carbon dioxide and in excreta (C).

The results obtained were summarized in Fig. 1. The body weight from the 4 th day to 10 th day after feeding the experimental diets remained almost unchangeable in the range of daily variation. Nitrogen balance resulted in negative on the lysine-free diet and the lysine requirement for nitrogen equilibrium was not mote than $0.25 \%$ of the diet.

Generally speaking, when an amino acid is present in suboptimal amounts in the diet, a large proportion of this amino acid will be used for protein synthesis. As its dietary supply exceeds the animal needs for protein synthesis, increased use of its carbon skeleton for alternative processes may be expected.

As shown in Fig. $1-(\mathrm{C})$, the recovery percentage of ${ }^{14} \mathrm{C}$ of injected dose in respiratory carbon dioxide remained at $6.1 \%$ on both the zero and $0.25 \%$ of dietary lysine level and thereafter increased rapidly with the increment of dietary lysine level. These results indicate that the lysine requirement of roosters may not be larger than $0.25 \%$ level of the diet. The recovery percentage of ${ }^{14} \mathrm{C}$ in excreta did not increase significantly.

The radioactivity of carbon dioxide liberated by tissue homogenates increased linearly with the incremental level of dietary lysine without any clear-cut break point as observed in respiratory studies. From the data obtained by this nitrogen balance method and oxidation technique, it may be concluded that lysine is essential for maintenance of adult roosters and its requirement is $0.25 \%$ or not greater than $0.25 \%$ level of the diet.

The effect of dietary lysine levels on the concentration of plasma free lysine was not determined in these studies. 
OHNO and TASAKI ${ }^{11}$ ) reported that the plasma lysine concentration remained constant as the dietary lysine level rose from 0.21 to $0.63 \%$, but increased linearly with the further increase of the dietary lysine level from 0.63 to $1.47 \%$. From the above results, they concluded that a lysine level greater than $0.63 \%$ was in excess of the amount needed by 8 -month-old cockerels fed a $3 \%$ casein diet. This higher estimation than our results shown in the above experiments may be partly due to the age of roosters used as ZIMMERMAN and Scorr ${ }^{12}$ already suggested. They reported that the lysine requirement was $0.83,0.70,0.67$ and $0.59 \%$ of the diet for 2-, 3-, 4- and 5-week-old chicks, respectively.

\section{References}

1) Ishrbasm, T., Jap J Zootech Sci 44: 39-49. 1973.

2) Leveille, G. A., and H. Fisher, J Nutr 66: 441-453. 1958.

3) Leveille, G. A., and H. Fisher, J Nutr 69: 289-294. 1959.

4) Leveille, G. A., and H. Fisher, J Nutr 70: 135-140. 1960.

5) Leveille, G. A., R. Shapiro, and H. Fisher, J Nutr 72: 8-15. 1960.

6) Ishibashi, T., Jap J Zootech Sci 43: 463-469. 1972.

7) Ishibashi, T., and M. KameTaKA, Jap J Zootech Sci 46: 677-683. 1975.

8) Ishibashi, T., and M. Kametaka, Agr Biol Chem 40: 809-810. 1976.

9) National Academy of Science-National Research Council, Washington, D. C. 1972.

10) Wang, S., and M.C. Nesheim, J Nutr 102: 583-596. 1972.

11) OHNo, T., and I. TASAKI, J Nutr 102: 603-608, 1972.

12) Zimmerman, R.A., and H. M. Scott, J Nutr 87: 13-18, 1965. 